International Journal for Crime, Justice and Social Democracy

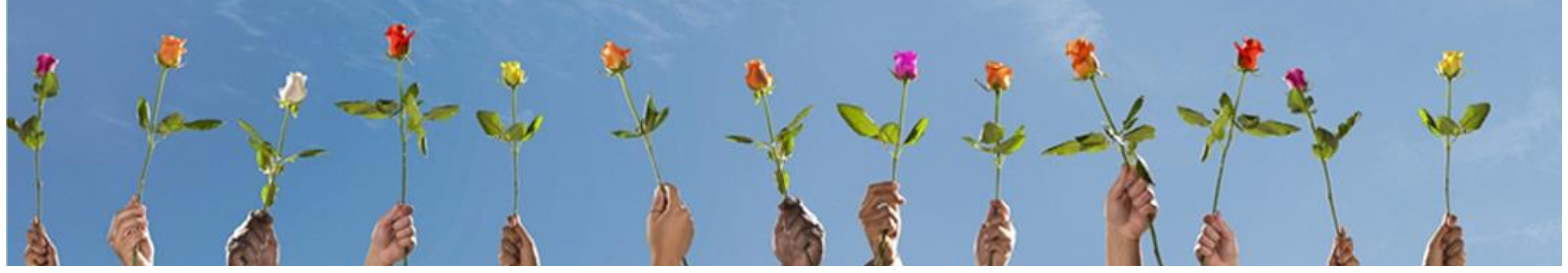

\title{
The Kilwa Massacre: Critical Analysis for a Southern Criminology
}

\author{
Kim Lah and Anthony Collins
}

La Trobe University, Australia

\begin{abstract}
This paper explores the 2004 Kilwa massacre in the Democratic Republic of the Congo (DRC) through a decolonial perspective, explaining how the massacre is situated within the history of colonial power and global capitalist relations. As such, the convergence of mining and political interests that created the context in which this violence was possible is examined, rather than the specific human rights abuses committed during the massacre. This approach highlights how such acts of violence are an ongoing factor of colonial and postcolonial exploitation, as well as the difficulties in holding the responsible parties accountable. This investigation shows the importance of developing a decolonial Southern criminology that contextualizes human rights abuses within local and international systems of power and locates acts of criminal violence within the broader networks of structural violence.
\end{abstract}

\section{Keywords}

Colonialism; Global South; structural violence; DRC; Southern criminology; decolonial theory.

Please cite this article as:

Lah K and Collins A (2020) The Kilwa massacre: Critical analysis for a southern criminology. International Journal for Crime, Justice and Social Democracy. 9(4): 135-147. https://doi.org/10.5204/ijcjsd.v9i2.1397

Except where otherwise noted, content in this journal is licensed under a Creative Commons Attribution 4.0 International Licence. As an open access journal, articles are free to use with proper attribution. ISSN: 2202-8005

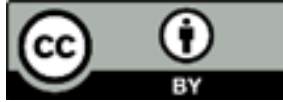


The greatest evil is not ... done in those sordid "dens of crime" that Dickens loved to paint. It is not done even in concentration camps and labour camps.

In those we see its final result. But it is conceived and ordered ... in clean, carpeted, warmed and well-lighted offices, by quiet men with white collars and cut fingernails and smooth-shaven cheeks who do not need to raise their voice. (CS Lewis 1961: xxxvii)

\section{The Massacre}

In 2004, President Joseph Kabila gave an order for military action that led to the massacre of civilians in the mining town of Kilwa in the Democratic Republic of Congo (DRC). Partially Australian-owned company, Anvil Mining (Anvil), helped to carry out this order by assisting the military. Kabila gave the order in response to a small number of insurgents who allegedly threatened the mine's operations. A report compiled by Rights and Accountability in Development (2007) asserts that civilians who were not affiliated with the insurgents were rounded up by Kabila's soldiers. They allege the soldiers detained, tortured, sexually abused and then executed up to 70 civilians. Investigations by various non-governmental organizations (NGOs) allege interference by military personnel in their investigations, as well as a conflict of interest between the government and Anvil (United Nations Mission in the Democratic Republic of Congo 2005; Rights and Accountability in Development 2007; Global Witness 2011).

On October 142004 at 2 am, 20-year-old Alain Kazadi (who claimed to be the leader of a rebel group) briefly occupied Kilwa with six or seven of his followers. The insurgents entered the local police station claiming they had the support of all military and politicians in the Katanga region and asked the police to join them. The Chief of Police and at least seven other officers allegedly joined the rebels (United Nations Mission in the Democratic Republic of Congo 2005: 3). The group then stole weapons from the local army base and accumulated another 40 members throughout the day. Kazadi held a public meeting in the town and announced Katanga's independence, claiming that "the time for pocketing the money from the mines was over for President Kabila" (United Nations Mission in the Democratic Republic of Congo 2005: 4). After approaching Anvil's fuel yard, Kazadi asked an Anvil employee to contact Anvil's management. The UN's (2005: 4) report states, "The insurgents insisted all the time they had not come to disturb the activities of the company." The employee declined to negotiate and, by late morning, the insurgents were instructed to go home, have lunch, and then meet again in the afternoon. The UN report claims that, at this point, "an estimated $90 \%$ of the 48,000 inhabitants of Kilwa chose to flee" (2005: 4). Without any official radio announcements to confirm Kazadi's claims, the fleeing inhabitants suspected a military response was imminent. During this time, Anvil closed operations and evacuated its staff via chartered planes. The mining company used the return flights to fly soldiers into Kilwa and sent Anvil trucks to Pweto (109 mi away) to collect soldiers.

President Kabila ordered the town "re-captured" within 48 hours. The following day, Colonel Ademars led the $62^{\text {nd }}$ brigade of the Armed Forces of the Democratic Republic of Congo (FARDC) in an attack on the town of Kilwa without offering any warning to its inhabitants. The FARDC bombarded Kilwa, demolishing several houses, before entering the town and engaging in a twohour firefight with the insurgents. No FARDC casualties were recorded. A report on the incident compiled by Rights and Accountability in Development (2011: 2) states: "Remaining civilians, mostly men and boys, were rounded up by soldiers and accused of supporting the rebels. Soldiers looted property and carried out other serious human rights violations including summary executions, sexual violence, torture, arbitrary detentions, pillage and extortion." Reports vary, but it is estimated that up to 70 civilians were killed. 
Anvil's involvement in the Kilwa massacre was significant. The United Nations Organization Mission in the Democratic Republic of Congo (MONUC) allege that Anvil transported soldiers to Kilwa by road and air and supplied trucks to the army for their use during the attack (MONUC 2005; Rights and Accountability in Development 2007; Global Witness 2011). Additionally, MONUC (2005) confirmed that three Anvil employees drove trucks during the attack. McBeth (2008: 134) concurs, stating: "Eyewitnesses reported that Anvil vehicles were used to transport looted goods, corpses, and detainees, some of whom were destined for execution." MONUC (2005: 8) confirmed that Anvil provided food to FARDC and "contributed to the payment of a certain number of soldiers." Further, according to MONUC (2005), their investigation into the incident was marred by interference from the military. They allege General Alengbia delayed their mission by a day and sent military personnel ahead of them to warn the Kilwa residents not to cooperate with MONUC. Moreover, in trying to ascertain the number of victims presented to Kilwa hospital, MONUC was prevented from being given information. Notably, Colonel Ademars had arranged a meeting with hospital staff the day before MONUC's arrival (United Nations Mission in the Democratic Republic of Congo 2005: 6). During an interview on Four Corners, the president and CEO of Anvil, an Australian named William Turner, admitted that Katumba Mwanke (a close adviser of President Kabila) was on the board of directors of Anvil Mining. Anvil also admitted that Mwanke was paid to attend Anvil meetings and that Anvil's headquarters were on property owned by Mwanke (United Nations Mission in the Democratic Republic of Congo 2005). This convergence of interests is highly significant and raises questions over accountability and legality regarding transnational mining companies such as Anvil. In the same interview, Turner responded to questions about his company's involvement with FARDC and its subsequent supply of logistical support with 'So what? So what?' (United Nations Mission in the Democratic Republic of Congo 2005: 8). Semantics over legality of such actions are evidenced here by Turner, rather than ethical considerations.

In 2005, the governor of Katanga invited the NGOs investigating the Kilwa incident to a meeting with Turner. In the presence of Turner, the governor told the NGOs that "they should defend the mining companies and not discourage investors" (Rights and Accountability in Development 2007: 7). After Four Corners aired their investigation into the Kilwa incident, Colonel Ademar (who had recently been arrested on unrelated charges) was charged with war crimes and other offenses regarding the Kilwa invasion. Shortly after, in August 2005, Anvil produced a requisition order for logistical support for FARDC that was written to them from the then governor of Katanga. The letter was dated eight months after the incident (Rights and Accountability in Development 2007: 5-7). Significantly, this alleged requisition order was not mentioned in any investigations prior to Ademar's arrest, nor did Turner mention it in his Four Corners interview. In 2006, a military trial was conducted in the DRC to investigate the massacre, resulting in the indictment of Colonel Ademar, eight other FARDC soldiers, Anvil, and three of Anvil's employees (Rights and Accountability in Development 2007: 9). Crucially, Rights and Accountability in Development (2007: 9) note that "Only in the event of Anvil Mining employees being found guilty would Anvil Mining the company be liable." The trial acquitted all involved. In its decision, the court referred to President Kabila's order to re-take the town, and judged that "no summary executions had occurred in Kilwa, but that people had been killed during 'fierce' fighting between the rebels and the FARDC" (Rights and Accountability in Development 2007: 25). The United Nations High Commissioner for Human Rights, Louise Arbour stated:

I am concerned at the court's conclusions that the events in Kilwa were the accidental results of fighting, despite the presence at the trial of substantial eyewitness testimony and material evidence pointing to the commission of serious and deliberate human rights violations. (Rights and Accountability in Development 2007: 25; see also Global Witness 2011) 
Arbour also expressed dismay about the use of a military court to try civilians. In this instance, it is apparent that the convergence of interests outlined earlier provided Anvil Mining and its employees with protection from prosecution. As head of the military, President Kabila's orders provided legal protection to both the soldiers and Anvil employees involved in the massacre.

\section{A History of Colonial Violence}

A decolonial perspective requires that we place these events in social and historical context. Considering these contexts deters an uncritical western perspective that ignores atrocities in the Global South, which may result in a lack of empathy for those imagined as different and serve as a tacit explanation of these events (i.e., they were the inevitable outcome of intrinsically violent and corrupt cultures). Colonial notions of native savagery and the failed African state are not simply unhelpful, they are actively misleading.

The collusion between violence and corporate interests has a long history in the Congo. Since the Congo's colonization by Belgian King Leopold in the late nineteenth century, economic exploitation has been a trademark of the region. King Leopold's methods of extracting materials from the Congo Free State (CFS) and its people endowed him with immense wealth. Military men acted as Leopold's agents in the hunt for lucrative natural resources and the land and its people belonged to Leopold under the terms the local chiefs unwittingly signed. Hochschild (1998: 72) notes that the treaties "bought not just land, but manpower." The pursuit of rubber caused the most heinous crimes perpetrated in the Congo-Congolese were kidnapped, raped, mutilated, and murdered (Morel 1904; Morel 1919). CFS agents often looted the villages, kidnapping women and holding them ransom until their husbands supplied the required amount of rubber (Anstey 1966). A journal entry by a missionary in the CFS reported: "Each time the corporal goes out to get rubber, cartridges are given to him. He must bring back all not used; and for every one used, he must bring back a right hand ... he informed me that in six months, they, the State, on the Momboyo River had used 6000 cartridges" (as cited in Anstey 1966: 7). Mr. E. Stannard provides a firsthand account of such atrocities in a letter included in Edmund Morel's King Leopold's Rule in Africa (1904). In the letter, Stannard recounts seeing severed hands and cannibalism (Morel 1904: 444). Stannard witnessed the agents taking "prisoners and shooting, and killed Bongingangoa, his wife; Boali his little daughter of about five years of age" (Morel 1904: 444). By 1908, a prolific and relentless campaign by the Congo Reform Association called attention to these atrocities. Consequently, the Belgian parliament held an inquiry into Leopold's CFS (Louis and Stengers 1968) and the investigation was then passed on to the Belgian Government. The estimated death toll for this period - 1891 to 1908 - ranges from 6-8,000,000 lives (Hochschild 1998: 3).

The Belgian Congo (as the CFS was renamed) put an end to state-sanctioned terror. However, the state remained a colony with a ruthless legacy. The Congo's primary purpose "was to develop 'the economic action of Belgium'" (Nzongola-Ntalaja 2002: 79). Accordingly, the Belgian Government contracted companies to build more infrastructure, offering them access to the natural resources of the Congo in return. Further, the Belgian Government developed a policy of recruiting tribal chiefs as their agents to ensure Congolese productivity remained high. Anstey (1966: 47) states, "The Chief was to be paid a salary ... he was given explicit administration and police powers, and wider criminal jurisdiction in small matters as of right. The chief continued, of course, to be subject to European control and surveillance."

Decimated though they were by colonization, their history is not without resistance movements. Various indigenous uprisings and rebellions occurred from the beginning, but proved futile. Nonetheless, regular protests were held in the lead up to independence in 1960 (NzongolaNtalaja 2002: 82). By 1958, the thirst for independence had grown substantially and Patrice 
Lumumba, Cyrille Adoula, and Joseph Ngalula formed the nation's first political party, The Congolese National Movement (Anstey 1966). In May 1960, the Congolese held their first free elections and voted in Lumumba as Prime Minister. By June 1960, the Belgian King, Baudouin, officiated the nation's independence from Belgian rule at the National Independence Ceremony.

Lumumba's commitment to political and economic freedom from Belgium threatened Western economic and military interests. Hickel (2017: 122) states, "The US feared Lumumba would loosen their grip on the Congo's vast mineral resources, including the uranium they relied on for their nuclear program and the cobalt they needed for their jet engines." Two months later, US President Eisenhower ordered Lumumba's assassination (Hickel 2017: 121). Post-assassination, the US backed a coup in which Mobutu Sese Seko was installed as president, leading to decades of political tyranny that protected western economic interests. Mullins and Rothe (2008: 89) state that "In addition to looting his own country, Mobutu was infamous for extrajudicial executions, civilian massacres and a host of other crimes against humanity." In 1997, the Congolese began to turn against Mobutu who were still not benefitting from the immense wealth being extracted from their land. His armed forces rebelled, and he quickly lost authority and was deposed from his presidency. Later that year, former guerilla chief turned gold and ivory trader, Laurent Kabila, announced himself as the Congo's new president. In 2001, Kabila was assassinated by his bodyguard, Rachidi Kasareka (Nzongola-Ntalaja 2002: 504). The following day, the late President's son, Major-General Joseph Kabila, was announced as the new president of the DRC. He retained this position until 2019.

There is a complex interplay of colonial violence within the specific events of the Kilwa massacre. Moreover, it is difficult to decide who is to be held responsible - the soldiers who committed the acts, the military commanders of the operation, the president who ordered military action, the Anvil employers who delivered soldiers to the scene, or the company bosses who instructed them to provide assistance to the military. Further, should the underlying social and historical conditions, the deliberate creation of a corrupt and underdeveloped state, and the willful collusion of international business interests and this government be examined? It is important to avoid both the tendency to only see violence as criminal acts of individual aggressors and the risk of erasing notions of agency and responsibility by focusing only on structural inevitability.

\section{An Exemplary Australian}

William Turner is not only a specific powerful decisionmaker, but also a symbolic representative of the way in which Western business interests play out in the developing world and how these interests are represented in the business' home country. Since Anvil's acquittal in the DRC, Turner is yet to face any sanction for his involvement in the massacre. On the contrary, he was awarded an Order of Australia (AO) in 2016. Bestowed on Australia's best and brightest, the AO is a prestigious honor. Turner received this illustrious award for "distinguished service to the mining sector and international relations through leadership in business and exploration between Australia and Africa" (Cosgrove 2016). Though he is now retired from his CEO position, Turner remains a powerful player in the mining sector. He is chairman of Geo40 Limited, which "will be the first company to commercialise, in large scale, the extraction of silica from geothermal fluids" (Geo40 Limited 2020). Until late 2019, Turner also served as director of Australia-Africa Minerals and Energy Group (AAMEG), a "peak body representing Australian companies engaged in the development of Africa's resource industry" (AAMEG 2019). While grappling with the conundrum of corporate crime and individual morality, Hills (1987: 190) states: "How is it possible that people who are basically moral and decent in their own families-perhaps even generous in civic and charitable contributions-are able to engage in corporate acts that have extraordinarily inhumane consequences?" More specifically, how do we reconcile the two versions of Turner we are presented with: law-abiding, celebrated mining executive in Australia and an alleged 
facilitator of human rights atrocities in the DRC? Turner was not accused of deliberately plotting human rights abuses; however, he played a key role in maintaining a corrupt relationship between Anvil and the Kabila regime to ensure the company's interests were politically protected. Further, Turner provided logistical support for military actions against citizens, which might reasonably have been predicted to carry the risk of human rights atrocities.

The notion of the "banality of evil" was explored by philosopher Hannah Arendt in her book Eichmann in Jerusalem: A Report on the Banality of Evil (1994). Arendt attempts to understand the role of high-ranking German Nazi officer Adolf Eichmann during the holocaust. Eichmann's job was to "organise the transportation of Jews from around Europe to extermination camps" (Morton 2004: 80). Post WWII, Eichmann was kidnapped from a hideout in Argentina and put on trial in Jerusalem. He was charged with being a principal orchestrater of the holocaust, thus becoming the face of unimaginable evil. Arendt, herself Jewish, attended the trial and, controversially at the time, theorized that Eichmann was not inherently evil or harboring hateful motives, but that his faithful adherence to orders resulted in evil acts. Regarding Eichmann's motives, Arendt (1994: 287) states, "Except for an extraordinary diligence in looking out for his personal advancement, he had no motives at all. And this diligence was, in itself, in no way criminal; he certainly would never have murdered his superior in order to inherit his post. He merely, to put the matter colloquially, never realised what he was doing." Further, Morton (2004: 80 ) concurs that an "exaggerated sense of duty and obedience" motivated Eichmann, rather than any sadistic intent. In Arendt's account, Eichmann was simply a morally vacuous bureaucrat who ensured the trains ran on time with no thought of the consequences of the logistical infrastructure he managed.

For Arendt, the distinction between evil intent and evil acts is central to her theory on the banality of evil. She contends that evil acts perpetrated as a result of banal thoughtlessness are no less evil than crimes perpetrated with evil intent. Hence, though Eichmann's actions came from a banal desire to follow orders and be a good officer, they were evil. Arendt (1994: 288) states "that such remoteness from reality and such thoughtlessness can wreak more havoc than all evil instincts taken together which, perhaps, are inherent in man-that was, in fact, the lesson one could learn in Jerusalem." Moreover, as Eichmann was obeying the orders of his government, his crimes were legal, which further complicates our understanding of evil. While the average person may understand the holocaust as evil, at the same time it is difficult to comprehend the legal and systematic structure that was required to carry out this genocide. Indeed, during an Australian Broadcasting Company interview regarding his role in the Kilwa massacre, Turner defended himself: "This was a military action conducted by the legitimate army of the legitimate government of the country" (Nolan 2005). Like Eichmann, Turner revealed no evil intent toward the victims of the massacre-he simply regarded supporting the military actions of a repressive government to ensure an ostensibly corrupt convergence of interests as his business because it is a rational business strategy. However, in some sense, this action is evil.

Concerning Eichmann's trial, Arendt (1994: 289) states, "In its judgement the court naturally conceded that such a crime could be committed only by a giant bureaucracy using the resource of government." Eichmann himself seemed confused that he should be considered evil and protested throughout the trial that he was simply following orders and doing his job. Arendt (1994: 293) argues, "Eichmann acted fully within the framework of the kind of judgement required of him: he acted in accordance with the rule, examined the order issued to him for its legality." As such, the court in Jerusalem found itself in unprecedented legal territory: how can a court try a man for "legal" crimes that were ordered and directed by a legal government? Here, an important distinction between morality and legality must be made, revealing how difficult it is to legally apportion guilt for administrative genocides (or legal massacres). In this regard, the law is inadequate for handling the trial of an atrocity enabled by lawful orders. 
Literary masterpiece Heart of Darkness is based largely on Joseph Conrad's (2007) experience in the Congo and wrestles with similar themes. The book's protagonist, Mr. Kurtz, is described as "the mysterious figure whose moral compass has apparently gone haywire" (Butcher; as cited in Conrad 2007: xiv); he represents key colonial pioneers in the Congo. For Conrad, the lack of accountability inherent in the colonization of the Congo region exposed the inhabitants to extreme corruption and abuse of power. A central theme emerges for Arendt and Conrad alike: the capacity for evil is within us all. Arendt's shock at discovering that Eichmann was not pathologically sadistic, but ordinary, dull, and banal, led her to theorize that he (and evil itself) could not be "othered." Given the same conditions, anyone could become an "Eichmann" by fulfilling their socially prescribed role without any critical reflection on its consequences. Similarly, Turner is an individual thoughtlessly acting out the destructive interests of a greater social system and an unreflective embodiment of the violence in the processes he directs.

Impersonal and bureaucratic in nature, transnational corporations (TNCs) and the crimes associated with them can be conceptualized through Arendt's (1994) banality of evil theory. As she outlines, it is the dehumanizing process of bureaucracy that enables ordinary people to commit unethical acts without ever having to consult their conscience; thus, making state and corporate crimes ethically ambiguous. Moreover, the relationship between capitalism and the law further complicates the issue. In Australia, consumers are purportedly protected by Australian Consumer Law, which requires businesses to, "report deaths, serious injuries or illnesses associated with consumer goods. This requirement is known as 'mandatory reporting'. All participants in the supply chain of a consumer goods or a product-related service are required to comply with the reporting requirements" (2018). Further, failure to report the above can result in corporate criminal convictions and a fine of up to A $\$ 1.1$ million (Australian Consumer Law 2018). However, the advance of globalization has allowed Western companies to conduct much of their business practice in vulnerable developing countries that are beyond the reach of these legal regulations. Under neoliberal globalization, nation-states' ability to hold corporations accountable for their international actions is diminished. Box (1983; see also Hills 1987) argues that fines provide little incentive for corporations to act ethically. Hills (1987: 201) contends that fines are dealt with by TNCs as an "overhead business expense." Illustrating this, a 1978 court case against Ford Motor Company in the US revealed that the manufacturing of a fuel tank Ford knew to be faulty was predicated on "a cost-benefit analysis" (Swigert and Farrell 1981: 166). Swigert and Farrell argue, "Officials at Ford allegedly predicted the number of severe burn injuries and deaths that would result from the defect and estimated that the cost of repairing the car would exceed anticipated court settlement" (1981: 166). Therefore, the ease with which corporations circumvent the economic cost of fines ultimately renders fining redundant.

Internal corporation structures and cultures that influence employee decision-making are crucial in understanding corporate crime. Hills (1987: 191) posits that "the internal organisational climate-the corporate subculture-is not typically an environment suffused with ethical sensibilities and discussions of social responsibility. Instead, quantifiable performance criteria based on production goals ... pervade the corporate atmosphere." Corporate players are rewarded for being singularly effective at generating profits and, like Eichmann, for following the orders of their superiors. Moreover, they are effectively socialized to avoid dwelling on the potentially disruptive moral ramifications of these actions. In the competitive market-driven environment of corporations, employees who display "moral flexibility" (Box 1983: 39) are rewarded with promotions and the comfort of financial stability (or an A0, as in Turner's case). Box (1983: 39) argues, "Not only does the promotion system mean that people who rise to the top are likely to have just those personal characteristics it takes to commit corporate crime, but these are also reinforced by the psychological consequences of success itself, for these ... free a person from the moral bind of conventional values." Further, the higher up the chain executives go, the more power they wield. Box (1983: 41) states, "moral flexibility will experience a further 
development when they have to respond to the relatively unaccountable and unconstrained power of being at ... the top." Such unrestricted power requires the individual to rely, almost exclusively, on their moral code. Yet, as elucidated above, those operating at the upper echelons of corporate power have already displayed a predisposition for "moral flexibility." Consequently, the global systems of exploitation and violence both produce and reward the types of individuals who ensure those systems achieve their goals.

Exemplifying a model corporate citizen, William Turner's efficient commitment to profit as Anvil's CEO evokes Lewis' (1961) softly spoken, "smooth-shaven" evil doer and Arendt's indifferent evil doer. Further, a legal court was inadequate to prosecute the state crimes ordered by former President Kabila and perpetrated through his armed forces (who were aided by Anvil Mining) because the crimes were ordered by a legal government. The court's reference to the president's order to capture the town during its decision to acquit all involved requires critical scrutiny. Having established that banal indifference can and does result in evil and atrocious acts, regardless of intent, and that legality is not synonymous with morality, the notion of corporate actors' agency is important.

Whether corporate employees are able to object or refuse to comply with directives they consider immoral must also be examined. Regarding the culture of organizations and their role in corporate crime, Mullins and Rothe (2008: 88) state, "it must be acknowledged that the perpetrators and decision makers in these cases possess agency. They are not automatons blindly responding to socio-political forces, but rather, lively social actors who often wield large amounts of social power and institutional authority." As such, those actors implicated in corporate crime can be understood as releasing themselves from the responsibility to critically reflect on potentially harmful consequences of their decisions; thus, choosing to abandon their humanity for the banal desire of career advancement. The challenge here is to understand both the conditions that produce these corporate actors and the consequences of their chosen actions. To overcome this challenge, it is crucial to consider the context of meaning in which their societies make sense of them and they make sense of themselves.

This analysis revealed that corporate conduit William Turner was richly rewarded for abandoning his conscience. He reached the top of the corporate chain and received the economic benefits and prestige of that position. Further, the Australian Government bestowed on him its highest honor-the AO. He is recognized as both a consummate corporate player and an exemplary Australian citizen. As Turner received an AO after the events at Kilwa, one could conclude that the Australian Government is willing to actively avert recognition of violence in the service of economic exploitation, which is rather more comfortably framed as "distinguished service to the mining sector and international relations" (Cosgrove 2016). From a decolonial perspective, it could be argued that Australia is implicated in and continues the legacy of the statecorporate exploitation in the Congo that was established by King Leopold and perpetuated by his successors.

\section{Global Profits, Global Violence}

According to Karl Marx (1992), exploitation is an inherent feature of wealth creation in a capitalist system. A rudimentary understanding of Marx's theory is that capitalism requires the exploitation of natural resources and people's labor, which is necessary to generate profit. Further, low labor and production costs are essential in the creation and exchange of commodities. As such, capitalism's constant need to drive down production costs to increase profits is the engine of this exploitation. Expanding on Marx's theory, Garry Leech (2012) theorizes that capitalism has its own internal logic and this logic serves the interests of those in positions of power. Leech (2012: 26) argues, "according to the logic of capital, society exists to serve the economy, rather than the 
reverse." Therefore, the production of profits and capital accumulation take precedence over human well-being.

Historically, the benefactors and stakeholders of a free market economy have influenced governments to intervene on their behalf. Proponents of free market capitalism, such as Milton Friedman (2002: 2), assert that the role of government in a market-based economy is to "preserve law and order, to enforce private contracts and to foster competitive markets." Further, Friedman (2002: 4) argues that democracy itself cannot exist in the absence of a free market economy. To this end, the "rule of law" plays a crucial role in prioritizing the interests of capital in a liberal democratic system. As such, Leech (2012: 25) argues that the market and the rule of law are inextricably linked within Western capitalist democracies.

Central to capitalism's growth and, therefore, Western dominance, is capitalism's genesis in colonialism. Vandana Shiva (2005: 19) argues that the "Key to the domination of the market economy is its ability to claim resources from outside its scope." As reflected in the history of the Congo, colonialism's legacy is one of exploitation and plunder: first of people, then of raw materials. Moreover, Anthony Anghie (2004; see also Grovogui 1996; Koskenniemi 2001) argues that colonialism was legitimized and facilitated by international law and created specifically for the needs of colonizers. In particular, the period between 1890 and 1914 is associated with the greatest profits for colonizers. This was the time of Leopold's reign in the Congo-a time of unprecedented suffering that culminated in the genocide of millions (Hochschild 1998).

Simultaneously, a combination of pervasive racism and Christian ideology provided a convenient backdrop for colonial rhetoric. Decolonial theorist Samir Amin (2011: 106) states that "The dominant discourse of the time praised colonisation (its civilising mission) and described globalisation as synonymous with peace." This very tactic was employed with aplomb by King Leopold during his campaign for the Congo and his subsequent rule (Hochschild 1998: 42). Leopold's "humanitarian" mission to the Congo was, in reality, the pursuit of his own personal fiefdom and the antithesis of a humanitarian mission. Similarly, contemporary TNCs praise themselves for job creation and economic development, ignoring the violent consequences of deliberately operating in areas that allow them to ruthlessly exploit labor and the environment, and often actively support the political powers that prevent protections against these abuses and use violence against their own citizens to advance the interests of those corporations.

By the 1950s, independence movements in the Congo and across the globe presented a threat to European and US corporate interests. Western governments, in particular the US, toppled governments, orchestrated coups, and installed leaders sympathetic to their interests to continue exploiting postcolonial states (Hickel 2017). By the 1970s and 1980s, the Western zeitgeist had developed a moral sensitivity and awareness of human rights issues; thus, explicit neocolonial violence was less acceptable. Consequently, another ideological discourse was required to allow the continued plundering of postcolonial states (i.e., development aid). Henry Kissinger, then US Secretary of State, used the United Nations to influence postcolonial member states to vote in the interest of Western states in exchange for aid (Nzongola-Ntalaja 2002). Crucially, this aid was attached to conditions that required recipient nations to be organized around transnational economic interests rather than the interests of their citizens. Further, these conditions required redirecting revenue away from nation-building public services and toward debt repaymentpreventing these nations from developing (Hickel 2017: 154; Klein 2007; Leech 2012).

The concept of structural violence provides a useful framework for understanding how the logic of economic exploitation historically guided imperialism. Developed to analyze social injustice and inequality, Johan Galtung's (1969) theory of structural violence aims to understand how structures within institutions, businesses, governments, and the like, cause intentional and 
unintentional suffering systematically and indirectly. Violence was and is an essential tool for imperialism and colonial exploitation. If capitalism cannot exist without exploitation, then it cannot exist without violence.

Typically, violence is understood as the threat or use of direct physical force by an individual or group against another individual or group. However, according to Galtung (1969), structural violence occurs when society is organized in a way that prevents groups of people from meeting their basic needs and causes them harm through adverse life outcomes. The important conceptual distinction is between the traditional definition of direct violence (i.e., a malicious agent threatens or harms a victim with physical force) and the less visible systemic forms of harm: poverty, insecurity, lack of basic human rights and freedoms, and the absence of the social conditions for good health and well-being. Structural violence is not always deliberately orchestrated in a malicious way, but often simply serves the interests of the privileged at the expense of the marginalized.

Importantly, while instances of direct violence can be attributed to an individual or group, which enables prosecution, structural violence is more difficult to attribute to specific perpetrators and thus harder to conceptualize within a criminal justice framework. Galtung (1969: 170) argues, "ethical systems directed against intended violence will easily fail to capture structural violence in their nets-and may hence be catching the small fry and letting the big fish loose."

Galtung (1969: 179) advances the idea that structural violence is the direct result of systems established to benefit "those who are at the top." As such, it is in the interest of those in power and the beneficiaries of said systems to maintain the status quo. Insidiously, those in positions of power have various armed forces at their disposal to quell any threat to the status quo. Therefore, maintenance of structural violence is often supported by direct violence when the system and its beneficiaries are threatened. Galtung (1969: 179) argues:

one has to observe carefully, for the most interested in the maintenance of the status quo may not come openly to the defence of the structure: they may push their mercenaries in front of them ... and remain themselves in more discrete, remote seclusion from the turmoil of personal violence.

This pattern has been highlighted repeatedly in the history of the Congo; from its inception, powerful elites have used various militias at their disposal to uphold their structurally violent regimes. King Leopold remained a continent away from the maiming and mutilating tactics his regime used to enforce his structurally violent colonial venture. To maintain control over the Congo's natural resources post-independence, US President Eisenhower ordered Prime Minster Lumumba's assassination from the "seclusion" of the white house, while his mercenaries on the ground engaged in the "turmoil" of direct violence. Hickel (2017: 122) states that "Lumumba was shot, chopped to pieces and burned to ashes in a barrel." More recently, President Mobuto and President Kabila have been accused of using their armed forces to terrorize, intimidate, and massacre their own people in their pursuit of personal wealth (Nzongola-Ntalaja 2002; Young and Turner 1985; McBeth 2008). The violent removal of the democratic government and the general state of underdevelopment and poor social infrastructure serve to ensure that Western interest continues to have access to cheap mineral resources at the minor cost of supporting compliant political tyrants. Kabila and Turner's alleged collusion regarding Anvil's assets in Kilwa continues this trend.

As a victim of structural and direct violence for over a century, the DRC has been crippled by imperialism. It currently has one of the worst Human Development Index rankings in the world14 from the bottom of 189 countries that are ranked regarding "long and healthy life, being 
knowledgeable and have a decent standard of living" (United Nations Development Programme 2018). During the genocide caused by Leopold's colonial endeavors and Mobutu's brutal dictatorship, the DRC endured crimes against humanity, violence, and state-sanctioned terror. More recently, years of civil war and the government's inability to control militia groups has made the DRC one of the most dangerous places on earth. Though economically destitute, the nation is still rich in highly desired natural resources (Mullins and Rothe 2008: 91). Mullins and Rothe (2008: 96) state, "For transnational corporations, profitability is often the core driver of their actions in global systems. Politically and economically disorganised nations provide fertile grounds for asset enhancement."

The DRC's long history as a source of wealth for imperialist nations made it an attractive location for Anvil. Further, the application of violence via the DRC's armed forces and the DRC's alleged collusion with Anvil continues a long history of violence by colonial regimes for imperialist wealth creation. Understanding the way in which the capitalist organization of society serves the creation of profits rather than the interests of citizens aids understanding of Anvil's involvement at Kilwa. Under such principles, Anvil was required to protect its profit margins and, in the geopolitical context of the DRC, this structurally violent premise was expressed in a directly deadly manner that resulted in the death of over 70 civilians.

It is the contention here that William Turner receiving an $\mathrm{AO}$ after the events at Kilwa is not an anomaly or an oversight. Rather, the Australian Government, itself a legal bureaucracy, has enshrined the structurally violent logic of capitalism in law and rewarded Turner for his consummate efforts in wealth creation via neocolonial exploitation and violence. These actions are part of a long historical tendency to discount and misrepresent the violence of Western interests in developing countries, resulting in the failure to effectively prosecute this violence within a legal framework or even imagining it as a problem within international relations.

The typical notion of violence is exemplified in the Kilwa massacre, but it is crucial to recognize how TNCs actively support the poor social and legal infrastructure in places like the DRC and collude with corrupt and undemocratic governments. This allows TNCs to generate profits that would be impossible in countries with strong labor, environmental, and human rights protections. TNCs do not simply use these vulnerable spaces as opportunities for profiteering, but actively support the political regimes that deny these protections to their citizens. They utilize corrupt convergences of interest such as those illustrated through Katumba Mwanke-the personal adviser to president Kaliba who was given a position on the board of directors of Anvil. What needs to be addressed here is the deliberate entanglement of the economic interests of Kaliba's inner circle with those of the mining company, as well as Anvil's material support for the Kaliba Government's human rights abuses, which was revealed through the logistical support for the soldiers committing the massacre.

A study that only examined the technical legality of Anvil's role in the Congo was inadequate, as was the court in which the matter of the Kilwa Massacre was heard. What is needed is a Southern criminology (Carrington et al. 2018) that positions the massacre within global history and relations of power. It is crucial to examine specific issues of criminal justice in the Global South with an understanding of the international context in which they occur. Moreover, it should not simply be a Southern criminology, but a decolonial criminology. In this case, that means understanding this massacre within the long history of violent invasion and exploitation that was started by King Leopold and continued in the neocolonial violence of the assassination of Prime Minster Lumumba, the support of the dictator Mobutu, and the corrupt regime of Joseph Kabila. Notably, it is often no longer necessary for Western powers to send in overt military forces to achieve their economic goals. It is more convenient to support and collaborate with corrupt and repressive regimes within those vulnerable countries and create dependency through debt to 
force developing countries to adopt policies that favor the profits of international businesses over the well-being of their own citizens. Further, the most serious forms of harm are not necessarily the dramatic instances of human rights abuses witnessed in this massacre, but the pervasive social suffering of those on the receiving end of these forms of transnational exploitation-the individuals working in dangerous and underpaid conditions and lacking the basic material conditions for quality of life: education, medical welfare, safety, and social and political autonomy. The harms of this structural violence add to and far exceed the direct violence of invasion and political repression.

TNCs do not simply take advantage of these conditions and the cheap labor and natural resources they create, but they actively support them. As revealed through William Turner, while claiming to do the good work of job creation and economic development, TNCs receive accolades from the neocolonial centers of power to which they return their profits, rather than being held accountable for the structural violence that their "business as usual" entails. As such, a critical Southern criminology must also be a decolonial criminology of the West and the structural violence of its exploitation of vulnerable societies within normalized practices of transnational business endeavors.

\section{Correspondence:}

Kim Lah, Graduate Researcher and Casual Academic, Crime, Justice and Legal Studies, Department of Social Inquiry, La Trobe University, Bundoora, VIC 3083, Australia. Email: k.lah@latrobe.edu.au

Dr Anthony Collins, Department of Social Inquiry, La Trobe University, Bundoora, VIC 3086, Australia. Honorary Research Professor, Faculty of Arts and Design, Durban University of Technology, Durban, 4001, South Africa. Email: a.collins2@latrobe.edu.au

\section{References}

Anghie A (2004) Imperialism, Sovereignty and the Making of International Law. New York: Cambridge University Press.

Anstey R (1966) King Leopold's Legacy: The Congo Under Belgian Rule 1908-1960. London: Oxford University Press.

Amin S (2011) Ending the Crisis of Capitalism, or Ending Capitalism? Cape Town: Pambazuka Press.

Arendt H (1994) Eichmann in Jerusalem: A Report on the Banality of Evil. New York: Penguin Books.

Australia-Africa Minerals and Energy Group (2018) AAMEG Team. https://aameg.org/aboutaameg/aameg-team

Australian Consumer Law (2018) The Australian Consumer Law: A Framework Overview. http://consumerlaw.gov.au/files/2015/06/ACL framework overview.pdf

Box S (1983) Power, Crime, and Mystification. London: Routledge.

Carrington K, Hogg R, Scott J, Sozzo M and Walters R (eds) (2018) The Palgrave Handbook of Criminology and the Global South. Palgrave McMillan.

Conrad J (2007) Heart of Darkness. London: Vintage Books.

Cosgrove P (Governor-General) (2016) Australia Day 2016 Honours Lists. The Governor-General of the Commonwealth of Australia https://www.gg.gov.au/australia-day-2016-honours-lists

Friedman M (2002) Capitalism and Freedom. Chicago: University of Chicago Press.

Galtung J (1969) Violence, peace and peace. Research Journal of Peace Research 6(3): 167-191. https://doi.org/10.1177\%2F002234336900600301

Geo40 Limited (2020) Who We Are: Geo40's Directors, Management and Consultants. https://geo40.com/who-we-are 
Global Witness (2011) Kilwa Massacre: Timeline of Key Events 1998 to 2010. https://www.globalwitness.org/sites/default/files/library/Kilwa\%20timeline\%20-\%20EN\%20\%20November\%202010.pdf

Grovogui S (1996) Sovereigns, Quasi Sovereigns, and Africans: Race and Self-Determination in International Law. Minneapolis: University of Minnesota Press.

Hickel J (2017) The Divide. London: William Heinemann.

Hills S (ed.) (1987) Corporate Violence: Injury and Death for Profit. Maryland: Rowman \& Littlefield.

Hochschild A (1998) King Leopold's Ghost: A Story of Greed, Terror, and Heroism in Colonial Africa. Boston: Houghton Mifflin Company.

Klein N (2007) The Shock Doctrine: The Rise of Disaster Capitalism. London: Allen Lane.

Koskenniemi M (2001) The Gentle Civilizer of Nations. Cambridge: Cambridge University Press.

Leech G (2012) Capitalism: A Structural Genocide. London: Zed Books.

Lewis CS (1961) The Screwtape Letters. New York: Harper Collins.

Louis R and Stengers J (eds) (1968) E.D. Morel's History of the Congo Reform Movement. Oxford: Clarendon Press.

Marx K (1992) Capital: A Critique of Political Economy (Vol 1). London: Penguin.

McBeth A (2008) Crushed by an anvil: A case study on responsibility for human rights in the extractive sector. Yale Human Rights and Development Law Journal 11: 127-166.

Morel ED (1919) Red Rubber: The Story of the Rubber Slave Trade Which Flourished on the Congo for Twenty Years 1890-1910. Manchester: National Labour Press.

Morel ED (1904) King Leopold's Rule in Africa. Connecticut: Negro University Press.

Morton A (2004) On Evil. New York: Routledge.

Mullins C and Rothe D (2008) Gold, diamonds and blood: International state-corporate crime in the Democratic Republic of the Congo. Contemporary Justice Review, 11(2): 81-99. https://doi.org/10.1080/10282580802057678

Nolan, $\mathrm{T}$ (2005) Mining Company Implicated in Congo Massacre. $A B C, 6$ June, http://www.abc.net.au/am/content/2005/s1385283.htm

Nzongola-Ntalaja G (2002) The Congo: From Leopold to Kabila: A People's History. London: Zed Books.

Rights and Accountability in Development (2007) Kilwa Trial: A Denial of Justice. A Chronology-October 2004-July 2007. RAID.

Shiva V (2005) Earth Democracy: Justice, Sustainability and Peace. Cambridge: South End Press.

Swigert V and Farrell R (1981) Corporate homicide: Definitional processes in the creation of deviance. Law and Society Review 15: 161-182.

United Nations Development Programme (2018) Human Development Indices and Indicators 2018 Statistical Update.

http://hdr.undp.org/sites/default/files/2018 human development statistical update.pdf

United Nations Organisation Mission in the Democratic Republic of Congo (2005) Report on the conclusions of the Special Investigation concerning allegations of summary executions and other human rights violations perpetrated by the Armed Forces of the Democratic Republic of Congo (FARDC) in Kilwa (Katanga Province) on 15 October 2004. Kinshasa: United Nations.

Young C and Turner T (1985) The Rise and Decline of the Zairian State. Wisconsin: University of Wisconsin Press. 